F.A. Mansour ${ }^{1}$, orcid.org/0000-0002-6694-2725,

M. Ould-Hamou', orcid.org/0000-0002-8770-5323, A. Merchichi ${ }^{1}$, orcid.org/0000-0001-8136-601X, O. Güven ${ }^{2}$, orcid.org/0000-0002-5267-9153
1 - Laboratoire de Génie Minier, Département Génie Minier, Ecole Nationale Polytechnique, El Harrach Algiers, Algeria, e-mail: farid_aghilasse.mansour@g.enp.edu.dz

2 - Department of Mining Engineering, Faculty of Engineering, Adana Alparslan Türkeş Science and Technology University, Sarıçam Adana, Turkey

\title{
RECOVERY OF IRON AND PHOSPHORUS REMOVAL FROM GARA DJEBILET IRON ORE (ALGERIA)
}

Purpose. This research aims to promote the assay of iron and reduce the phosphorus grade of the final DRI.

Methodology. A high-phosphorus oolitic iron ore from Gara Djebilet deposit underwent the procedure of coal-based direct reduction (coal-based DR) followed by wet low-intensity magnetic separation (WLIMS). The effects of temperature, periods of time and $\mathrm{Na}_{2} \mathrm{SO}_{4}$ dosage on phosphorus removal, metallisation degree and iron recovery rate were tried and optimised. Furthermore, phase changes in iron oxides and the distributing features of phosphorus in both reduced and magnetic materials were investigated as well.

Findings. The appropriate addition of sodium sulfate improves the Fe-P separation during the coal-based DR of Gara Djebilet mixed pellets.

Originality. Using additives of $\mathrm{CaO}$ and sodium sulfate during the coal-based DR-magnetic separation of mixed pellets sourced from Gara Djebilet deposit.

Practical value. The results reveal that a final direct reduced powder (DRI) assaying $96 \mathrm{wt} \% \mathrm{Fe}$ and $0.16 \mathrm{wt} \% \mathrm{P}$ at a recovery rate of $97.72 \%$ was obtained when the ore-coal- $\mathrm{CaO}$ mixed pellets were reduced in the presence of $5 \mathrm{wt} \% \mathrm{Na}_{2} \mathrm{SO}_{4}$ at $1250{ }^{\circ} \mathrm{C}$ for $30 \mathrm{~min}$. Thus, the coal-based DR could be used as an alternative to the blast furnace (BF) route in the steelmaking industry from refractory iron ores.

Keywords: Gara Djebilet, high-phosphorus oolitic iron ore, coal-based direct reduction, sodium sulfate, magnetic separation

Introduction. The metallic iron recovery from refractory iron ores, as a substitute to easy-to-process iron ore resources, is a major global issue to deal with the fast increase in need for iron and relieve the threat of raw material shortage in steelmaking industry [1]. Nowadays, the extraction of metallic iron via the BF remains the most dominant route in steelmaking industry. However, it is neither cost-effective nor feasible for highphosphorus oolitic iron ores as almost elemental $\mathrm{P}$ is absorbed by hot liquid metallic iron owing to the high temperature of the procedure [2]. Phosphorus is a detrimental impurity in ferrous metallurgy, since it increases the brittleness and decreases the ductility and low-temperature toughness of steel products [3]. Several bench-scale tests have been conducted on promoting the beneficiation of high-phosphorus iron ores across the world. Available routes include hydrometallurgical and pyrometallurgical processes [4]. Froth flotation, gravity separation, magnetic separation, chemical leaching, and bioleaching are the main hydrometallurgical processes. The pyrometallurgical processes such as magnetisation roasting, microwave heating, gas-based reduction, and coal-based DR are promising routes for the production of DRI. The direct reduction (DR) prior to the electric arc furnace (EAF) is an alternative route to the standard BF process. It has been proven satisfactory for metallic iron recovery from fines, pellets, sinter and lump by converting them into DRI using several materials as reductant at reduction temperatures below the melting point of iron $(\mathrm{Fe})$ [5]. This study focuses on the recovery of metallic iron and the removal of phosphorus from mixed pellets sourced from Gara Djebilet deposit via the procedure of coal-based DR followed by WLIMS. The effects of temperature, time periods and sodium sulfate dosage on the metallisation degree and the recovery rate of magnetic separation were investigated. In addition, phase changes in iron oxides during reduction process and the spreading features of phosphorus in both reduced and magnetic materials were investigated and discussed.

Materials. The ironstone samples used in this research were gathered from the Gara Djebilet deposit in Tindouf prov-

(c) Mansour F. A., Ould-Hamou M., Merchichi A., Güven O., 2021 ince of Algeria. The chemical and mineralogical compositions of the raw ore sample are presented in Table 1 and Fig. 1 respectively.

The results show that the total iron (TFe) grade is up to $53.2 \mathrm{wt} \%$ and exists in the form of hematite, magnetite, goethite and maghemite. However, the assay of phosphorus amounts to $0.8 \mathrm{wt} \%$ and occurred as fluorapatite. $\mathrm{SiO}_{2}$ exists as quartz and $\mathrm{Al}_{2} \mathrm{O}_{3}$ distributes in chamosite. Fig. 2 presents photomicrographs of the raw ore observed under the ore microscopy (Nikon Eclipse LV100POL) and the cathodoluminescence microscopy (CITEL MK5-2 CLM). It is clear from Fig. 2 that the oolitic texture is made of ooids having the shape of ovals ranging from $150 \mu \mathrm{m}$ to $800 \mu \mathrm{m}$ in size. The non-detrital facies (FOND) of magnetitic ore (Fig. 2,a) and nonmagnetitic ore (Fig. 2,b) correspond to scattered ooids in a quartz-poor groundmass. In the cemented facies (FOC) of non-magnetitic ore (Fig. 2,c), the chamositic spastoliths and ooids with chamositic nucleus and swapping hematitic-chamositic layers are bounded together by a hematitic matrix. Apatite exists as prismatic crystals in both ooids and groundmass. The groundmass apatite is light-green luminescing, while the detrital apatite in grains and oolite laminae exhibits brightyellow green emission (Fig. 2, $d$ ).

Detrital grains of quartz are present only in the detrital facies (FOD) and occur as anhedral grains of different sizes (Fig. 2,e). Pyrite (light cream) and chalcopyrite (yellow) are very rare and occur within burrows of the ore (Fig. 2, $f$ ). Bituminous coal sourced from Bechar province of Algeria was used as reductant in the tests. The components of coal were assayed on an air-dried basis and the outcomes are listed in Table 2.

Calcium oxide $(\mathrm{CaO})$, used as flux, and the additive of sodium sulfate $\left(\mathrm{Na}_{2} \mathrm{SO}_{4}\right)$ were of analytical reagent (AR) grade and their size is less than $74 \mu \mathrm{m}$.

Methods. The raw ore and coal were crushed and screened separately to $100 \%$ less than $1 \mathrm{~mm}$ by means of a laboratory jaw crusher. Then, iron ore samples were blended with coal and $\mathrm{CaO}$ according to particular proportions by rigorously stirring during 30 minutes. The quantity of excess coal in the mixture was determined according to $\mathrm{C} / \mathrm{O}$ molar ration of 2 
Table 1

Chemical composition of raw iron ore sample (wt\%)

\begin{tabular}{|l|c|l|c|}
\hline $\mathrm{TFe}$ & 53.20 & $\mathrm{MgO}$ & 0.42 \\
\hline $\mathrm{SiO}_{2}$ & 07.19 & $\mathrm{MnO}$ & 0.23 \\
\hline $\mathrm{Al}_{2} \mathrm{O}_{3}$ & 05.96 & $\mathrm{TiO}_{2}$ & 0.13 \\
\hline $\mathrm{Fe}_{2} \mathrm{O}_{3}$ & 63.17 & $\mathrm{P}_{2} \mathrm{O}_{5}$ & 1.84 \\
\cline { 1 - 2 } $\mathrm{FeO}$ & 11.55 & $\begin{array}{l}\text { Loss on } \\
\text { ignition (LOL) }\end{array}$ & 7.15 \\
\cline { 1 - 3 } $\mathrm{CaO}$ & 02.36 & & \\
\hline
\end{tabular}

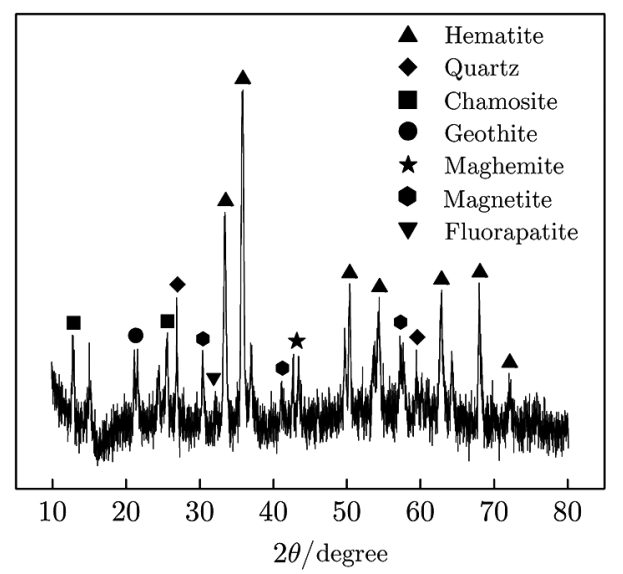

Fig. 1. X-ray diffraction pattern of Gara Djebilet oolitic iron ore sample
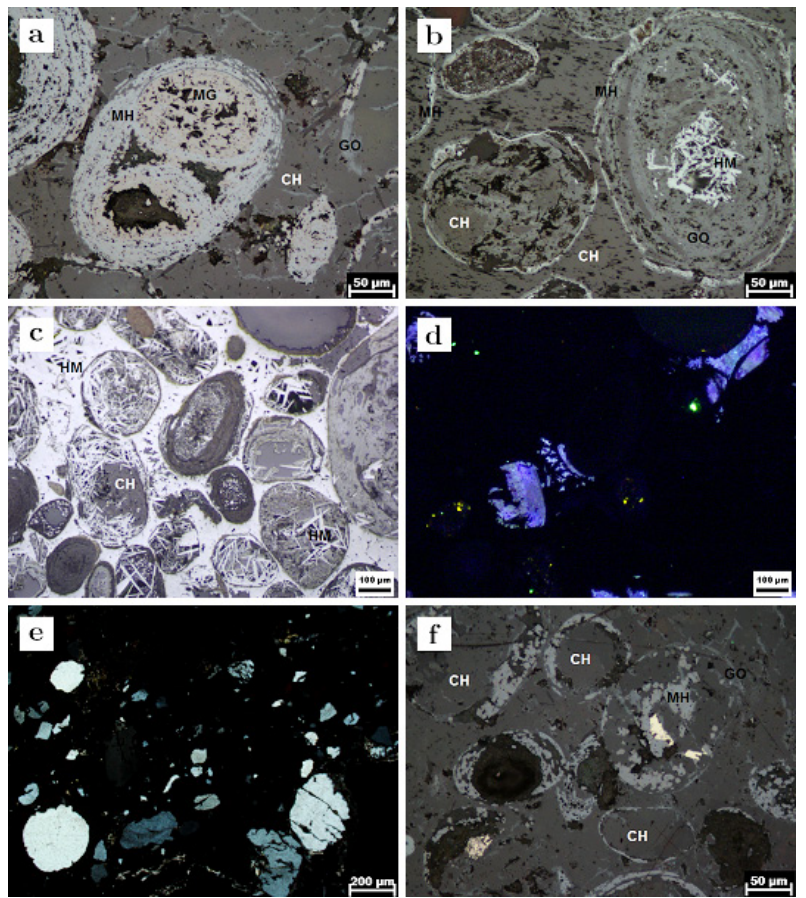

Fig. 2. Photomicrograph collages of ironstone samples:

$\mathrm{CH}$ - chamosite; $\mathrm{GO}$ - goethite; HM - hematite; $\mathrm{MH}$ - maghemite; $M G$ - magnetite

Table 2

Results of proximate analysis of coal

\begin{tabular}{|c|c|c|c|c|c|}
\hline $\mathrm{TC}$ & $\mathrm{FC}_{\text {dry }}$ & $\mathrm{V}_{\text {dry }}$ & $\mathrm{A}_{\text {dry }}$ & $\mathrm{M}_{\text {dry }}$ & $\mathrm{S}$ \\
\hline 69.06 & 49.54 & 45.28 & 6.18 & 14.95 & 0.66 \\
\hline
\end{tabular}

$\mathrm{TC}$ - total carbon; $\mathrm{FC}_{\mathrm{dry}}$ - fixed carbon; $\mathrm{V}_{\mathrm{dry}}$ - volatile matter; $\mathrm{A}_{\mathrm{dry}}-\mathrm{ash} ; \mathrm{M}_{\mathrm{dry}}-$ moisture (i.e. the molar ratio of fixed carbon in the coal to reducible oxygen in the iron oxides was 2 ). $\mathrm{CaO}$ was added to attain the predetermined binary basicity of 1 (i. e. the mass ratio of $\mathrm{CaO}$ to $\mathrm{SiO}_{2}$ was 1). Each run requires $20 \mathrm{~g}$ iron ore sample, $13 \mathrm{~g}$ coal and $1.6 \mathrm{~g} \mathrm{CaO}$. An appropriate amount of water (12 wt\%) was added to the prepared mixtures and subsequently pressed into cylindrical pellets using a steel die with a size of $30 \mathrm{~mm}$ diameter and a thickness of $8 \mathrm{~mm}$ with the aid of a hydraulic press, and thereafter dried in drying oven at $105^{\circ} \mathrm{C}$ for 4 hours. The reduction trials were performed in a high-temperature electric resistance muffle furnace (MoS-B 170/8 Protherm Furnace). First, the pellets were charged into heat-resistance graphite crucibles, and a layer of coal (about $1 \mathrm{~mm}$ thick and 2 grams weight) was spread over the top surface of the pellets to assure the reducing atmosphere within the crucibles. Then, the mixtures were reduced under the designated experimental conditions in the furnace which had already been heated to the various desired reduction temperatures. Meanwhile, purge gases were not utilized during the roasting and the tests were run at atmospheric conditions. After reduction, the charged crucibles were withdrawn from the furnace and cooled down to the room temperature under an air-isolated environment. Once the mixtures in the crucibles cooled, a part of reduced mixed pellets were polished for SEM-EDS analyses, and the remainder were milled to $80 \%$ less than $74 \mu \mathrm{m}$ using a vibratory disc mill.

Then, a random sample weighing $20 \mathrm{~g}$ deducted from each of the milled products and slurried to $20 \mathrm{wt} \%$ solids by weight, was divided into concentrate and tailing fractions through a Davis magnetic tube tester (KHD Humboldt Wedag International AG, Germany) at a magnetic field intensity of $110 \mathrm{kAm}^{-1}$; after that, the magnetic products were filtered and dried in a vacuum drying oven at $105 \pm 5^{\circ} \mathrm{C}$ for 24 hours. The evaluation indices of test results were assessed by the iron metallisation degree $\eta(\%)$ and the iron recovery rate $\varepsilon(\%)$ of DRI powder. $\eta$ is calculated according to the following formula

$$
\eta=\frac{\delta_{\mathrm{Fe}}}{\alpha_{\mathrm{Fe}}} \cdot 100,
$$

where $\delta_{\mathrm{Fe}}$ is the metallic iron content of the reduced material (wt\%); $\alpha \mathrm{Fe}$ is the total iron content of reduced material (wt\%).

Whereas, $\varepsilon$ is calculated according to the following formula

$$
\varepsilon=\frac{m_{2} \beta_{\mathrm{Fe}}}{m_{1} \alpha_{\mathrm{Fe}}} \cdot 100
$$

where $m_{1}, m_{2}$ are the dry weight of feed and concentrate materials respectively $(\mathrm{g}) ; \beta_{\mathrm{Fe}}$ is the total iron content of magnetic material (wt\%).

The $\mathrm{P}$ content and Fe grade of both reduced and magnetic products were assayed using chemical analyses.

The mineralogical phases present in both reduced and magnetic materials (under selected roasting conditions) were identified by powder X-ray diffraction (XRD). The morphology and microstructure of reduced samples were observed using scanning electron microscopes equipped with an X-ray energy dispersive spectrum. Micrographs were taken and point EDS analyses were used to recognise local compositions.

Results and discussions. The effect of reduction temperature. The prepared pellets were sintered at temperature values of $1000,1100,1200$ and $1300{ }^{\circ} \mathrm{C}$ respectively. While the reducing period was fixed at $30 \mathrm{~min}$ and no sodium sulfate was added to the mixtures. The data revealed that, as the temperature varied from 1000 to $1300{ }^{\circ} \mathrm{C}, \eta, \beta_{\mathrm{Fe}}$ increased sharply from 74.52 to $92.36 \%$ and from 73.23 to $84.81 \mathrm{wt} \%$ respectively. Moreover, $\varepsilon$ exhibited a significant improvement from 86.35 to $94.36 \%$ (Fig. 3, $a$ ).

This is due to the fact that increasing further the reduction temperature improves the reduction of iron oxides, destroys the oolitic structure and promotes the iron grains growth [6]. However, there was a dramatic increase in $\beta_{\mathrm{P}}$ in the whole 


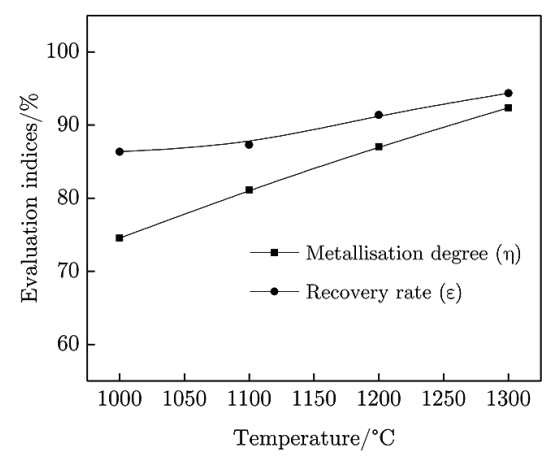

$a$

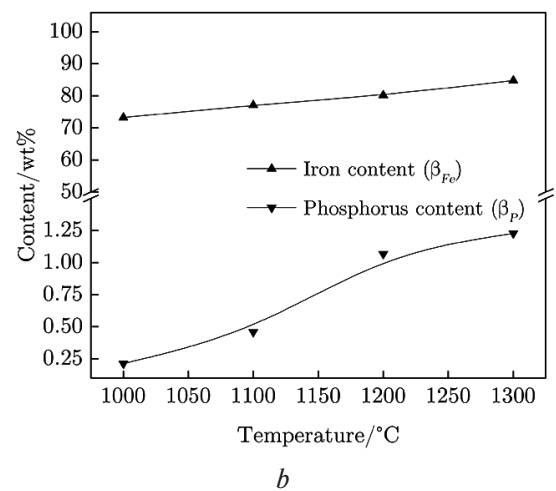

Fig. 3. Effect of temperature on the process evaluation indices (a) and on the iron and phosphorus contents of magnetic materials (b)

range of tested reduction temperatures to peak $1.23 \mathrm{wt} \%$ at $1300{ }^{\circ} \mathrm{C}$ (Fig. 3, $b$ ). This increase could be attributed to the reduction of fluorapatite to generate gaseous phosphorus $\left(\mathrm{P}_{2}\right)$ which, due to its high reactivity, melted into metallic iron rather than emitting to the atmosphere.

The effect of reduction time. A set of experiments were conducted at reduction periods of $15,30,45$ and $60 \mathrm{~min}$. The reducing temperature was set at $1250{ }^{\circ} \mathrm{C}$ and the experiments were run in the absence of sodium sulfate. Fig. 4 indicates that there was a marked rise in $\varepsilon$ and $\beta_{\mathrm{Fe}}$ to peak $96.21 \%$ and $88.88 \mathrm{wt} \%$ respectively at $30 \mathrm{~min}$, but then fell significantly over the next periods of time to approximately $92 \%$ and $81 \mathrm{wt} \%$ respectively.

Likewise, $\eta$ dropped sharply as the reduction periods exceed $30 \mathrm{~min}$ from 94.15 to $87.17 \%$. In effect, an additional extension in the periods of reduction can lead to a weakening of the reducing atmosphere due to the exhaustion of the reductant at this high temperature. Thus, the engendered metallic iron would be subjected to re-oxidation, leading to a decrease in both $\eta$ and $\varepsilon$ [6]. In addition, a further increase in reduction time, results in a dramatic rise in $\beta_{\mathrm{P}}$, and after the maximum reduction period $(60 \mathrm{~min})$, it was as high as $1.43 \mathrm{wt} \%$. This is due to the fact that more fluorapatite in the raw ore is reduced to $\mathrm{P}$, which migrates into the metallic phase as the reduction period is extended.

The effect of sodium sulfate dosage. The prepared mixtures were mixed thoroughly with a proper amount of water (12 wt\%) in the presence of various quantities of sodium sulfate.

Then, the mixtures were pressed into pellets and reduced at $1250^{\circ} \mathrm{C}$ for $30 \mathrm{~min}$, after having been dried in a vacuum oven at $105{ }^{\circ} \mathrm{C}$ for 4 hours. The results are presented in Fig. 5. The data show that both $\eta$ and $\varepsilon$ first increased sharply from 95.72 and $95.11 \%$ to 98.35 and $97.72 \%$ respectively as the $\mathrm{Na}_{2} \mathrm{SO}_{4}$ dosage varied from 2.5 to $5 \mathrm{wt} \%$, then declined obviously when the $\mathrm{Na}_{2} \mathrm{SO}_{4}$ dosage increased further up to $10 \mathrm{wt} \%$. Meanwhile, a marked rise is observed in $\beta_{\mathrm{Fe}}$ to peak 96 at $5 \mathrm{wt} \%$ $\mathrm{Na}_{2} \mathrm{SO}_{4}$. However, a further increase in the $\mathrm{Na}_{2} \mathrm{SO}_{4}$ dosage results in a slight decrease in $\beta_{\mathrm{Fe}}$ to reach $90.04 \mathrm{wt} \%$. Indeed, owing to the increase in $\mathrm{Na}_{2} \mathrm{SO}_{4}$ dosage, more $\mathrm{FeS}$ would be produced during the reduction process leading to a diminution

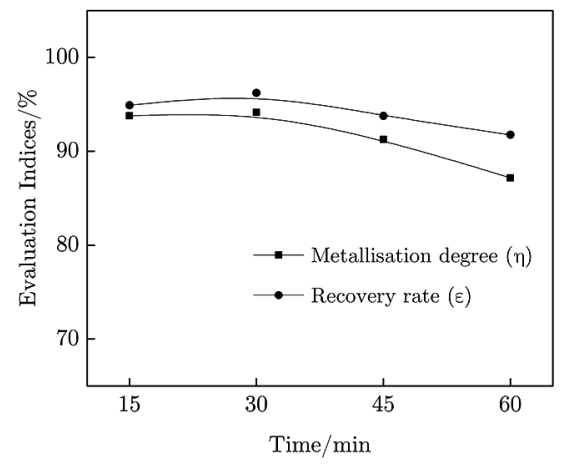

$a$

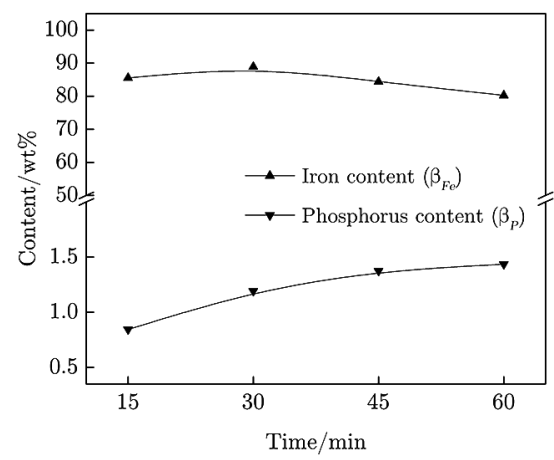

$b$

Fig. 4. Effect of time on the process evaluation indices (a) and on iron and phosphorus contents of magnetic materials (b)

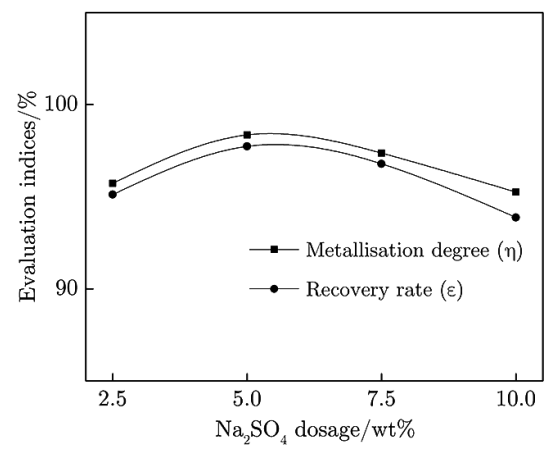

$a$

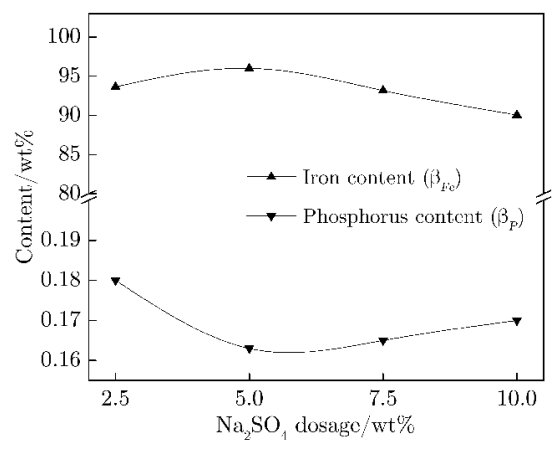

$b$

Fig. 5. Effect of sodium sulfate dosage on the process evaluation indices (a) and on the iron and phosphorus contents of magnetic materials (b) 
in $\beta_{\mathrm{Fe}}$ [6]. Conversely, increasing the $\mathrm{Na}_{2} \mathrm{SO}_{4}$ dosage from 2.5 to $5 \mathrm{wt} \%$, results in a sharp decrease in $\beta_{\mathrm{P}}$ from 0.18 to $0.16 \mathrm{wt} \%$. However, a slight increase is observed when the $\mathrm{Na}_{2} \mathrm{SO}_{4}$ dosage is beyond $5 \mathrm{wt} \%$ (Fig. 5, $b$ ).

Phase constitution of reduced pellets. In order to understand the aforementioned experimental results, selected reduced pellets were subjected to mineralogical analyses, and their XRD pattern is shown in Fig. 6. The results reveal that the peaks associated with $\mathrm{Fe}_{2} \mathrm{O}_{3}$ vanished completely due to its reduction to metallic iron stepwisely in the order of $\mathrm{Fe}_{2} \mathrm{O}_{3} \rightarrow$ $\mathrm{Fe}_{3} \mathrm{O}_{4} \rightarrow \mathrm{FeO} \rightarrow \mathrm{Fe}$ through gaseous intermediate of $\mathrm{CO}$ and $\mathrm{CO}_{2}$ resulting in fixed carbon gasification. In the absence of sodium sulfate, the $\mathrm{SiO}_{2}$ diffractions became less intense, and those of chamosite fade away. Meanwhile, the peaks associated with anorthite appeared after the reduction process, and became more intense with increasing the temperature (Fig. 6, c). This is attributed to the fact that a reaction between $\mathrm{Ca}_{5}\left(\mathrm{PO}_{4}\right)_{3} \mathrm{~F}, \mathrm{SiO}_{2}, \mathrm{CaO}$ and chamosite took place during the reduction process. Moreover, iron appeared most often in the form of metallic state which is easily recovered by WLIMS.

However, diffraction peaks associated with intermediate products like wustite and minor iron minerals such as fayalite $\left(\mathrm{Fe}_{2} \mathrm{SiO}_{4}\right)$ and hercynite $\left(\mathrm{FeAl}_{2} \mathrm{O}_{4}\right)$ appeared in the XRD pattern of reduced samples, suggesting that some $\mathrm{FeO}$ take part in reaction with $\mathrm{SiO}_{2}$ and chamosite during the reduction process, despite the consumption of some amount of these minerals in advance by $\mathrm{CaO}$. Therefore, $\eta$ is relatively low, and the $\mathrm{Fe}-\mathrm{P}$ separation is unsatisfied. These minor iron minerals are turned into non-magnetic materials which can reduce $\varepsilon$. Regarding the reduction in the presence of $\mathrm{Na}_{2} \mathrm{SO}_{4}$ (Fig. $6, d$ ), the XRD pattern shows new diffraction peaks attributed to nepheline $\left(\mathrm{NaAlSiO}_{4}\right)$, anorthite and $\mathrm{CaNaPO}_{4}$. Moreover, no peaks associated with quartz and chamosite are found in the reduced powder, suggesting that a reaction between $\mathrm{Ca}_{5}\left(\mathrm{PO}_{4}\right)_{3} \mathrm{~F}, \mathrm{SiO}_{2}, \mathrm{Al}_{2} \mathrm{O}_{3}$ and $\mathrm{Na}_{2} \mathrm{SO}_{4}$ took place during the reduction.

Over $800 \mathrm{~K}$, the formation of $\mathrm{NaAlSiO}_{4}$ is prior to that of anorthite and $\mathrm{CaNaPO}_{4}$, since $\mathrm{Na}_{2} \mathrm{SO}_{4}$ reacts more easily with $\mathrm{SiO}_{2}$ and $\mathrm{Al}_{2} \mathrm{O}_{3}$ than with $\mathrm{Ca}_{5}\left(\mathrm{PO}_{4}\right)_{3} \mathrm{~F}$, which prevent its reduction.

Meanwhile, the generated $\mathrm{CaNaPO}_{4}$ from the reduction of some fluorapatite is more stable in the absence of $\mathrm{SiO}_{2}$ and

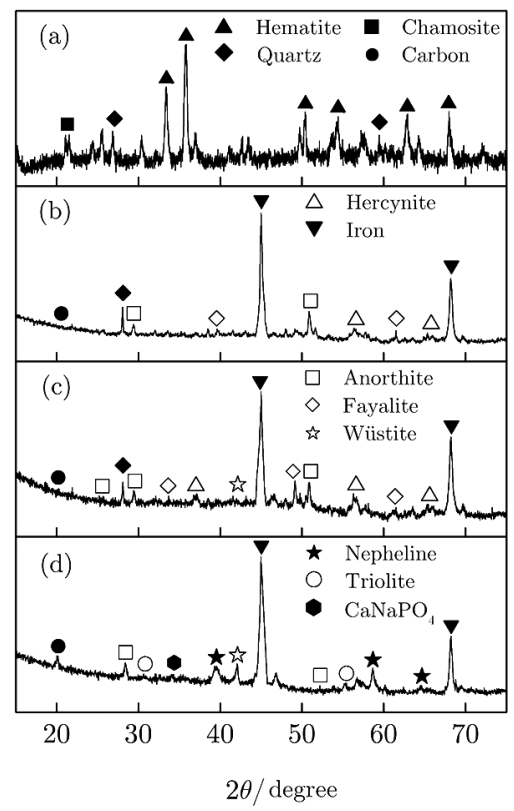

Fig. 6. XRD patterns of raw ore $\left(\right.$ a), pellet reduced at $1200{ }^{\circ} \mathrm{C}$ during $30 \mathrm{~min}(\mathrm{~b})$, pellet reduced at $1250{ }^{\circ} \mathrm{C}$ during $60 \mathrm{~min}$ (c), and pellet reduced in the existence of 10 wt $\% \mathrm{Na}_{2} \mathrm{SO}_{4}$ at $1250{ }^{\circ} \mathrm{C}$ during $30 \mathrm{~min}(\mathrm{~d})$
$\mathrm{Al}_{2} \mathrm{O}_{3}$, already consumed by $\mathrm{CaO}$ and $\mathrm{Na}_{2} \mathrm{SO}_{4}$, despite that the reduction temperature is over $1313 \mathrm{~K}$ [7]. In addition, $\mathrm{Na}_{2} \mathrm{SO}_{4}$ had reacted with $\mathrm{SiO}_{2}$ and $\mathrm{Al}$-bearing minerals in the raw ore, to generate $\mathrm{NaAlSiO}_{4}$ and anorthite $\left(\mathrm{CaAl}_{2} \mathrm{SiO}_{8}\right)$, in preference to wustite $(\mathrm{FeO})$, leading to a marked rise in the reducing reaction activity of $\mathrm{FeO}$ and thereby, $\eta$ gets obviously enhanced. Although most of iron in the reduced powder exists as metallic iron, but some non-magnetic iron minerals are also present in the reduced powder like wustite $(\mathrm{FeO})$, as well as a small amount of troilite $(\mathrm{FeS})$, which is greatly implausible to transform into $\mathrm{Fe}$ or $\mathrm{FeO}$ in the $\mathrm{CO}$ reducing atmosphere, since $\mathrm{FeS}$ could likewise be formed from $\mathrm{FeO}$ [7]. Furthermore, the unreduced fluorapatite turns into tailings along with non-magnetic materials. Therefore, $\varepsilon$ and the Fe-P separation get obviously improved.

Morphology and microstructure features of the reduced pellets. A sample reduced at $1250{ }^{\circ} \mathrm{C}$ for 60 min was investigated by SEM-EDS analysis (SEM-EDS, JEOL JSM-5410, Japan). The SEM image and the results of EDS measurements at several spots of both metallic and slag phases from the selected sample are presented in Fig. 7. After reduction, the iron oxides were reduced to metallic iron particles which clump together causing the destruction of the entire oolitic structure (Fig. 7, $a$ ). In the absence of sodium sulfate, the metallic iron particles had not combined to each other completely, and connected yet with gangue minerals. The results of point analysis show that $\mathrm{Si}, \mathrm{Ca}, \mathrm{Al}, \mathrm{O}$ are the main elements of spot 1 from the grey slag matrix phase and it may be $(\mathrm{Mg}, \mathrm{Fe}) \mathrm{SiO}_{4}$ and $\mathrm{CaAl}_{2} \mathrm{SiO}_{8}$. Meanwhile, the $\mathrm{Fe}$ content was higher than $13 \mathrm{wt} \%$, suggesting that many ultrafine iron crystallites had not grown and still associated closely with gangue minerals. Besides, the $\mathrm{P}$ content at point 2 amounted to $2.03 \mathrm{wt} \%$, which indicates that most of fluorapatite in the mixture was reduced and the new-born phosphorus melted into the metallic iron grains to generate phosphorus iron $\mathrm{Fe}_{x} \mathrm{P}$. This is due to the fact that, at these roasting conditions, more $\mathrm{FeO}$ will react with gangue minerals to produce low-melting point materials due to the poor reducing atmosphere supplied (the wide band proving the presence of glass phase materials was spotted between 10 and $40^{\circ}$ in the XRD pattern provided in Fig. 6, c) [8]. Since the existence of liquid phase is contributing to the spread of phosphorus-bearing particles to those of carbon, the reduction rate of fluorapatite $\left(\mathrm{Ca}_{5}\left(\mathrm{PO}_{4}\right)_{3} \mathrm{~F}\right)$ is improved and thereby more elemental $\mathrm{P}$ melted into metallic iron [9]. As the physical beneficiation ways are unable to remove the elemental $\mathrm{P}$ in metallic iron, high-phosphorus content DRI is acquired by WLIMS. The sample produced under optimal reduction parameters (reduced at $1250{ }^{\circ} \mathrm{C}$ for $30 \mathrm{~min}$ with adding $5 \mathrm{wt} \%$ $\mathrm{Na}_{2} \mathrm{SO}_{4}$ ) was investigated by SEM-EDS analysis (SEM-EDS, JEOL JSM-7610FPlus, Japan). The SEM photomicrograph and the outcomes of EDS measurements at diverse spots of both metallic and slag phases from the selected sample are presented in Fig. 8. As revealed in Fig. 8, $a$, most metallic iron grains are connected, presenting a net-like microstructure, and some small gangue particles (dark grey) are enveloped in the mesh. By adding sodium sulfate, the metallic iron grains (in bright white) aggregated together and grew in sizes mostly over $75 \mu \mathrm{m}$. Furthermore, the metallic phase was apart from the gangue phase with clear boundaries, which improves the liberation of metallic iron from slag matrix and thereby, a DRI with high metallic iron grade is acquired.

Fig. 8, $c$ reports that $\mathrm{Si}, \mathrm{Ca}, \mathrm{Na}, \mathrm{Al}, \mathrm{O}, \mathrm{P}$ are the main elements of spot 1 from the slag phase and it may be anorthite $\left(\mathrm{CaAl}_{2} \mathrm{SiO}_{8}\right)$, nepheline $\left(\mathrm{NaAlSiO}_{4}\right), \mathrm{CaNaPO}_{4}$ and the unreduced part of fluorapatite. Meanwhile, there was found less amount of $\mathrm{Fe}$, suggesting that iron grains and gangue minerals were less intergrown. Therefore, it is easy to attain a clean separation of iron from gangue by subsequent milling and WLIMS. The results of point analysis of spot 2 (Fig. 8, $d$ ) show that elemental phosphorus has not been spotted in the metallic iron phase (in bright white). This is because the addition of 

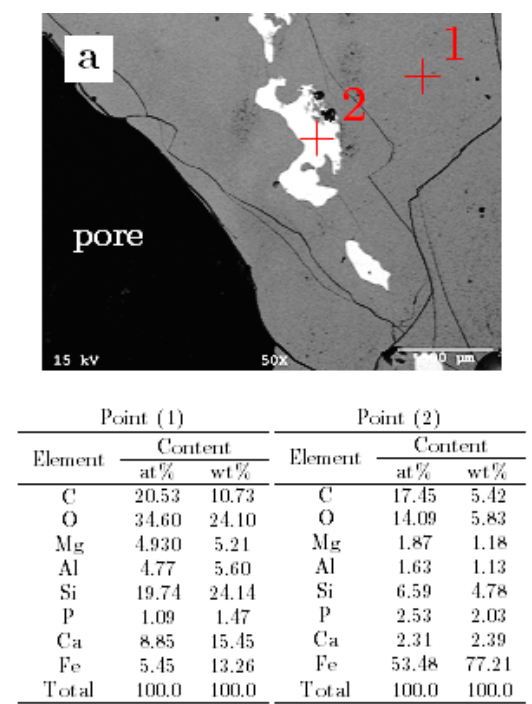
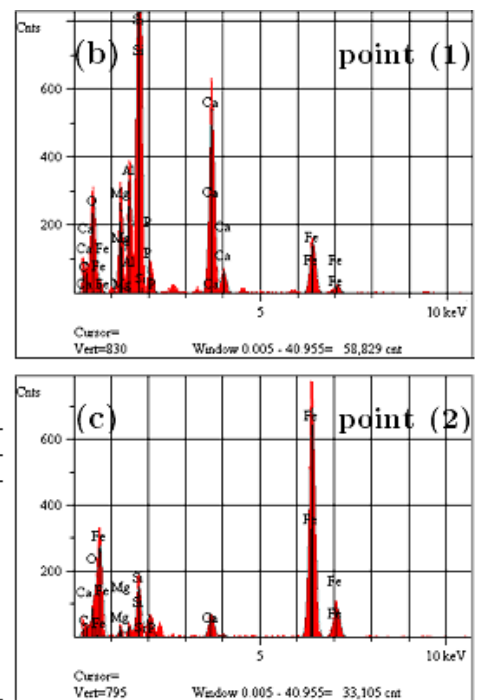

Fig. 7. SEM image (a) with EDS spectra of spot $1(b)$ and spot $2(c)$ from a reduced pellet at $1250{ }^{\circ} \mathrm{C}$ during 60 min in the absence of sodium sulfate

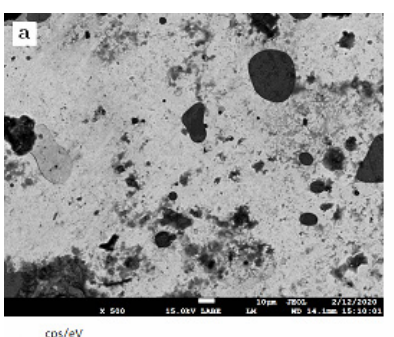

(c)

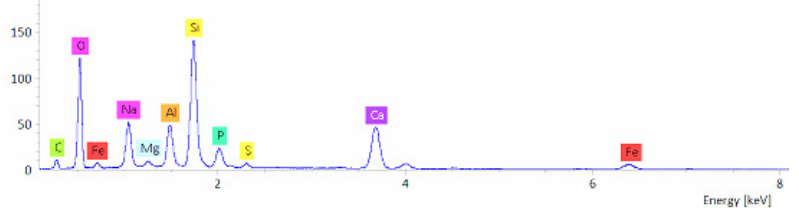

cpsev

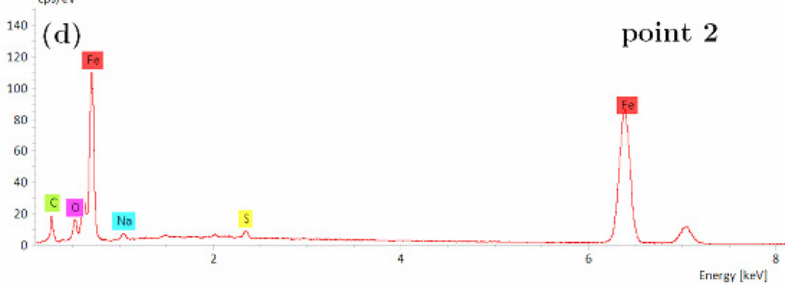

Fig. 8. SEM images (a) and (b) with EDS analyses of the slag (c) and metallic phase $(d)$ of the sample reduced at $1250{ }^{\circ} \mathrm{C}$ for 30 min with the addition of $5 \mathrm{wt} \% \mathrm{Na}_{2} \mathrm{SO}_{4}$

sodium sulfate hinders the reduction of $\mathrm{Ca}_{5}\left(\mathrm{PO}_{4}\right)_{3} \mathrm{~F}$ by the production of a liquid phase which accelerates the interaction between $\mathrm{SiO}_{2}, \mathrm{Al}_{2} \mathrm{O}_{3}, \mathrm{CaO}$ in the raw ore. However, there was found a little quantity of $\mathrm{S}$ in the metallic iron phase, and it may be troillite $(\mathrm{FeS})$, which reacts with Fe during the reduction process to generate a low-melting point $\mathrm{Fe}-\mathrm{FeS}$ eutectic system. The generation of the Fe-FeS liquid phase facilitates the mass transfer of metal ions and accelerates the metallic iron grains combination.

Distribution of phosphorus in the microstructure of DRI. In order to study the distribution of phosphorus in the DRI, the magnetic concentrate of the mixed pellet reduced at $1250{ }^{\circ} \mathrm{C}$ for $30 \mathrm{~min}$ in the absence of sodium sulfate was investigated by SEM-EDS analysis (FEI Quanta 250 ESEM, The Netherlands).

Fig. 9, $a$ shows that phosphorus exhibits a reticular distribution in DRI, and its content is high where elemental carbon distributes vigorously (Table 3) [10]. The affinity of phosphorus to metallic iron is quite associated with carburisation in the metallic phase and the particular texture of oolitic iron ore. Indeed, the ore is made up of numerous layers, and the iron oxides layers are joined with those of gangue minerals [11]. Therefore, previous to reduction of fluorapatite, the new generated metallic iron would envelop the unreduced fluorapatite layers. Once the fluorapatite is reduced, $\mathrm{P}_{2}$ permeates readily into DRI, already wrapped in the $\mathrm{Ca}_{3}\left(\mathrm{PO}_{4}\right)_{2}$ surface and the heterogeneous melting of the iron phase led to the reticular distribution $[10,11]$. By contrast, the reduction of fluorapatite becomes difficult in the existence of sodium sulfate, due to the consumption of $\mathrm{SiO}_{2}$ and $\mathrm{Al}_{2} \mathrm{O}_{3}$ before their reaction with the $\mathrm{P}$-containing minerals during the reduction process.

Characterization of magnetic concentrates. The magnetic concentrate obtained from reduction under optimal reduction parameters (reduced at $1250{ }^{\circ} \mathrm{C}$ for $30 \mathrm{~min}$ with adding $5 \mathrm{wt} \%$ $\mathrm{Na}_{2} \mathrm{SO}_{4}$ ) followed by grinding and WLIMS, was investigated using SEM-EDS analysis (Environmental FEI Quanta 250 SEM, The Netherlands) and the result is presented in Fig. 10. It is clear that the metallic iron grains occupied almost all the picture of the magnetic material (Fig. 10,a).

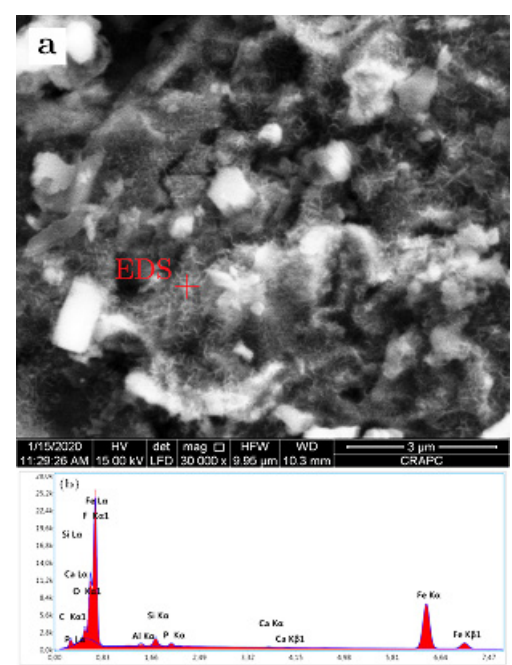

Fig. 9. The reticular distribution of phosphorus observed in the magnetic concentrate from the sample reduced at $1250{ }^{\circ} \mathrm{C}$ during 30 min in the lack of sodium sulfate (a) and the result of EDS measurement at the selected spot (b) 
Table 3

EDS quantitative analyses data of the selected spot from the magnetic material of the pellet reduced at $1250{ }^{\circ} \mathrm{C}$ for $30 \mathrm{~min}$ in the absence of sodium sulfate

\begin{tabular}{|l|c|c|}
\hline \multicolumn{1}{|c|}{ Element } & \% mass & \% atomic \\
\hline $\mathrm{C} \mathrm{K}$ & 3.92 & 11.88 \\
\hline $\mathrm{O} \mathrm{K}$ & 2.78 & 7.92 \\
\hline $\mathrm{F} \mathrm{K}$ & 0.92 & 2.20 \\
\hline $\mathrm{Al} \mathrm{K}$ & 0.65 & 1.10 \\
\hline $\mathrm{Si} \mathrm{K}$ & 1.59 & 2.58 \\
\hline $\mathrm{P} \mathrm{K}$ & 1.18 & 1.71 \\
\hline $\mathrm{Ca} \mathrm{K}$ & 0.33 & 0.38 \\
\hline Fe K & 88.62 & 72.22 \\
\hline
\end{tabular}

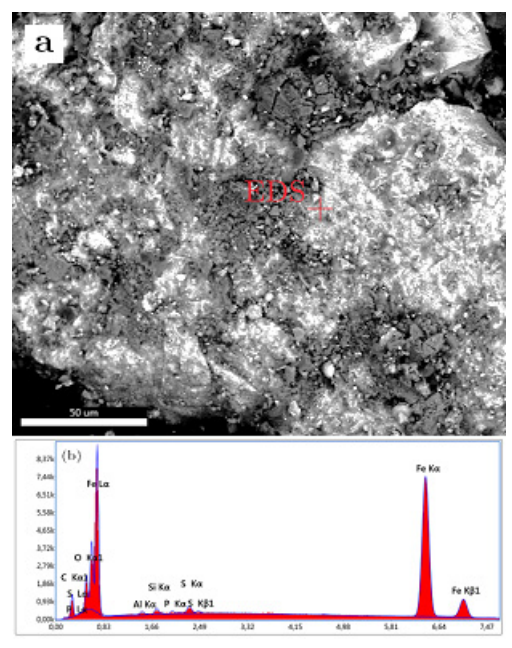

Fig. 10. Photomicrograph of magnetic concentrate from the pellet reduced at $1250{ }^{\circ} \mathrm{C}$ during $30 \mathrm{~min}$ in the presence of 5 wt $\% \mathrm{Na}_{2} \mathrm{SO}_{4}(a)$ and EDS analysis of the selected spot $(b)$

According to the EDS quantitative analysis data presented in Table 4, metallic iron is the main element detected in the magnetic product, suggesting that a nearly monophased DRI could be recovered under optimized roasting conditions.

Conclusion. The recovery of metallic iron and the efficiency of improving the Fe-P separation through the addition of a suitable quantity of sodium sulfate $\left(\mathrm{Na}_{2} \mathrm{SO}_{4}\right)$ during coal-based DR of iron ore-coal-CaO mixed pellets from the Gara Djebilet field were investigated. The characterization of the raw ore by both optical and cathodoluminescence microscopy reveals that iron oxides are completely disseminated and closely related

Table 4

EDS quantitative analysis data of the selected spot from the magnetic material of the pellet reduced at $1250{ }^{\circ} \mathrm{C}$ during $30 \mathrm{~min}$ in the presence of $5 \mathrm{wt} \%$ sodium sulfate

\begin{tabular}{|l|c|c|}
\hline \multicolumn{1}{|c|}{ Element } & \% mass & \% atomic \\
\hline $\mathrm{C} \mathrm{K}$ & 1.94 & 8.10 \\
\hline $\mathrm{O} \mathrm{K}$ & 1.42 & 4.25 \\
\hline $\mathrm{Al} \mathrm{K}$ & 0.30 & 0.56 \\
\hline $\mathrm{Si} \mathrm{K}$ & 0.55 & 0.84 \\
\hline $\mathrm{P} \mathrm{K}$ & 0.16 & 0.25 \\
\hline $\mathrm{S} \mathrm{K}$ & 0.18 & 0.28 \\
\hline Fe K & 95.44 & 85.72 \\
\hline
\end{tabular}

with gangue minerals. Moreover, the phosphorus content is as high as $0.8 \mathrm{wt} \%$, which makes it not suitable for steel industry.

When the mixed pellets were reduced at various high temperatures, without any additives, part of gaseous $\mathrm{P}_{2}$, generated by the reduction of fluorapatite, readily penetrates into the metallic iron rather than emitting to the atmosphere, resulting in a high phosphorus content of DRI. By contrast, a final DRI with $96 \mathrm{wt} \% \mathrm{Fe}$ and $0.16 \mathrm{wt} \% \mathrm{P}$ can be acquired at $\varepsilon$ of 97.72 by adding $5 \mathrm{wt} \% \mathrm{Na}_{2} \mathrm{SO}_{4}$ to the mixed pellets when reduced at $1250{ }^{\circ} \mathrm{C}$ for $30 \mathrm{~min}$. Furthermore, optical microscopy and SEM analyses of reduced pellets show that the oolitic structure is destroyed and metallic iron particles gathered together and grew significantly in sizes mostly over $75 \mu \mathrm{m}$ when reduced in the existence of sodium sulfate.

These results demonstrate that the coal-based DR could be used as an alternative to the BF for the steel production from Gara Djebilet oolitic iron ore.

Acknowledgement. The authors would like to thank Prof. M. S. Çelik and Prof. E. Çiftçi from Istanbul Technical University (ITÜ) for their precious help and assistance provided throughout this research.

\section{References.}

1. Luo, L., \& Zhang, H. (2017). Process mineralogy and characteristic associations of iron and phosphorus-based minerals on oolitic hematite. Journal of Central South University, 24(9), 1959-1967. https://doi. org/10.1007/s11771-017-3604-8.

2. Sun, Y., Han, Y., Gao, P., \& Yu, J. (2015). Size distribution behavior of metallic iron particles in coal-based reduction products of an oolitic iron ore. Mineral Processing and Extractive Metallurgy Review, 36(4), 249-257. https://doi.org/10.1080/08827508.2014.955611.

3. Yang, M., Zhu, Q.S., Fan, C.L., Xie, Z.H., \& Li, H.Z. (2015). Roasting-induced phase change and its influence on phosphorus removal through acid leaching for high-phosphorus iron ore. International Journal of Minerals, Metallurgy and Materials, 22(4), 346-352. https:// doi.org/10.1007/s12613-015-1079-X.

4. Quast, K. (2018). A review on the characterisation and processing of oolitic iron ores. Minerals Engineering, 126, 89-100. https://doi. org/10.1016/j.mineng.2018.06.018.

5. Hamadeh, H., Mirgaux, O., \& Patisson, F. (2018). Detailed modeling of the direct reduction of iron ore in a shaft furnace. Materials, 11(10), 1865-1871. https://doi.org/10.3390/ma11101865.

6. Zhu, D., Guo, Z., Pan, J., \& Zhang, F. (2016). Synchronous upgrading iron and phosphorus removal from high phosphorus oolitic hematite ore by high temperature flash reduction. Metals, 6(6), 1-17. https://doi.org/10.3390/met6060123.

7. Rao, M., Ouyang, C., Li, G., Zhang, S., Zhang, Y., \& Jiang, T. (2015). Behavior of phosphorus during the carbothermic reduction of phosphorus-rich oolitic hematite ore in the presence of $\mathrm{Na}_{2} \mathrm{SO}_{4}$. International Journal of Mineral Processing, 143, 72-79. https://doi. org/10.1016/j.minpro.2015.09.002.

8. Yu, W., Sun, T., Cui, Q., Xu, C., \& Kou, J. (2015). Effect of coal type on the reduction and magnetic separation of a high-phosphorus oolitic hematite ore. ISIJ International, 55(3), 536-543. https://doi. org/10.2355/isijinternational.55.536.

9. Cheng, C., Xue, Q., Wang, G., Zhang, Y., \& Wang, J. (2016). Phosphorus migration during direct reduction of coal composite highphosphorus iron ore pellets. Metallurgical and Materials Transactions $B, 47(1), 154-163$. https://doi.org/10.1007/s11663-015-0479-7.

10. Cheng, C., Xue, Q., Zhang, Y., Han, F., \& Wang, J. (2015). Dynamic migration process and mechanism of phosphorus permeating into metallic iron with carburizing in coal-based direct reduction. ISIJ International, 55(12), 2576-2581. https://doi.org/10.2355/isijinternational.ISIJINT-2015-386.

11. Li, G., Rao, M., Ouyang, C., Zhang, S., Peng, Z., \& Jiang, T. (2015). Distribution characteristics of phosphorus in the metallic iron during solid-state reductive roasting of oolitic hematite ore. ISIJ International, 55(11), 2304-2309. https://doi.org/10.2355/isiiinternational.ISIJINT-2015-212.

\section{Вилучення заліза й видалення фосфору із залізної руди Гара Джебілет (Алжир)}

Ф. А. Мансур ${ }^{1}$, М. Олд-Хатоу ${ }^{1}$, А. Мершиши ${ }^{1}$, О. Гувен $^{2}$ 
1 - Лабораторія гірничого машинобудування, Гірничий інженерний відділ, Національна політехнічна школа, Ель-Харраш Алжир, Алжир, e-mail: farid_aghilasse. mansour@g.enp.edu.dz

2 - Гірничий інженерний відділ, Інженерний факультет, Університет Науки та Технологій імені Адани Альпарслана Тюркеша, Саричам Адана, Туреччина

Мета. Дослідження щодо зниження вмісту фосфору в залізі, отриманого методом прямого відновлення із залізної руди.

Методика. Оолітова залізна руда з високим вмістом фосфору з родовища Гара Джебілет пройшла процес прямого відновлення на основі вугілля (ПВ на основі вугілля) 3 подальшою мокрою магнітною сепарацією в полі низької інтенсивності (WLIMS). Були досліджені та оптимізовані впливи температури, часу обробки й концентрація $\mathrm{Na}_{2} \mathrm{SO}_{4}$ на видалення фосфору, ступеня металізації та швидкості вилучення заліза. Також були досліджені фазові перетворення оксидів заліза та особливості розподілу фосфору як у відновлених, так і в магнітних матеріалах.
Результати. Відповідне додавання сульфату натрію покращує розділення $\mathrm{Fe}-\mathrm{P}$ під час прямого відновлення окатишів на вугільній основі родовища Гара Джебілет.

Наукова новизна. Використання добавки $\mathrm{CaO}$ і сульфату натрію під час прямого відновлення окатишів на основі вугілля родовища Гара Джебілет і подальшої магнітної сепарації.

Практична значимість. Результати показали, що остаточний продукт, отриманий прямим відновленням, містить $96 \%$ мас. Fe i 0,16\%мас. Р. Ступінь вилучення заліза склала 97,72\% коли гранули з суміші руда-вугілля-СаO відновлювалися з $5 \%$ мас. $\mathrm{Na}_{2} \mathrm{SO}_{4}$ за температури $1250{ }^{\circ} \mathrm{C}$ протягом 30 хв. Таким чином, ПВ на основі вугілля можна використовувати як альтернативний метод отримання металу з міцних залізних руд методу отримання металу в доменній печі (ДП) у сталеплавильній промисловості.

Ключові слова: Гара Джебілет, оолітова залізна руда з високим вмістом фосфору, пряме відновлення окатишів на основі вугілля, сульфат натрію, магнітна сепарація

Recommended for publication by Professor Mohammed Bachar Assed. The manuscript was submitted 09.03.21. 